\title{
Short communication \\ Pharmacogenetics and pharmacogenomics of endocrine agents for breast cancer
}

\author{
James $\mathrm{N}$ Ingle \\ Mayo Clinic, First Street SW, Rochester, MN 55905, USA
}

Corresponding author: James N Ingle, ingle.james@mayo.edu

Published: 18 December 2008

This article is online at $\mathrm{http}: / /$ breast-cancer-research.com/content/10/S4/S17 (c) 2008 BioMed Central Ltd

\section{Introduction}

The clinician caring for women with early breast cancer is keenly aware of the variability observed when endocrine therapy with tamoxifen or the aromatase inhibitors (Als) is employed. This is seen in outcomes of the disease in terms of recurrence but also, strikingly in some cases, in terms of adverse events. This can be seen in the case of Als, in which some women develop disabling musculoskeletal events that result in their discontinuing therapy, whereas the majority develops no such adverse events. The same is true of other adverse events such as deep venous thrombosis, endometrial cancer and hot flashes in the case of tamoxifen. In the past, the focus in selection of therapy for women with breast cancer has been almost exclusively on the characteristics of the tumour (for example, oestrogen receptor [ER] and human epidermal growth factor receptor [HER]-2), with essentially no attention given to the genetic make-up of the patient.

Pharmacogenetics and pharmacogenomics involve the study of the role played by inheritance in individual variation in drug response phenotypes such as disease outcomes and end organ effects, including adverse events. These terms are often used interchangeably but, strictly speaking, pharmacogenetics refers to the study of a gene or a number of genes, such as those involved with a pathway, whereas pharmacogenomics involves the entire genome. We have truly entered the era of pharmacogenomics with the introduction of genomewide association studies (GWASs). Pharmacogenetics/ pharmacogenomics have the clinical goals of better selecting responsive patients, maximizing drug efficacy and minimizing adverse reactions. Pharmacokinetics considers factors such as metabolism and transport that influence drug concentrations at the target(s), whereas pharmacodynamics considers factors that influence the response of the target(s), for example receptors, enzymes, transporters and downstream signalling molecules, to the drug.
Breast Cancer Research 2008, 10(Suppl 4):S17 (doi:10.1186/bcr2177)

Endocrine therapy represents the most important therapeutic modality for those women whose tumours are potentially endocrine sensitive, as indicated by expression of the ER and/or progesterone receptor. The selective ER modulator tamoxifen has been the most important therapeutic agent in breast cancer for the past three decades. Tamoxifen has received approval from the US Food and Drug Administration for the full spectrum of breast cancer from metastatic disease to those women who are at higher risk for developing breast cancer. In addition, tamoxifen has received approval for treatment of men with metastatic breast cancer and is commonly used in the adjuvant setting. During the past decade the third generation Als anastrozole, exemestane and letrozole have emerged as important additions to the clinician's armamentarium against breast cancer. They appear to be more efficacious than tamoxifen in the advanced disease setting [1], have become clearly established in the adjuvant setting [2] and are a major focus of ongoing trials in the prevention setting in postmenopausal women [3]. Tamoxifen and the Als have recently become foci of intense pharmacogenetic/pharmacogenomic research [4].

\section{Tamoxifen}

Interpatient variability exists in response to tamoxifen. The accepted dose of tamoxifen is $20 \mathrm{mg} /$ day, but there is substantial variability with respect to levels of tamoxifen and its metabolites. We examined steady-state levels of tamoxifen and two of its major metabolites, namely 4-hydroxy-tamoxifen $(4 \mathrm{HT})$ and $\mathrm{N}$-desmethyl-tamoxifen, and found substantial interpatient variability for all three; for instance, the median level for tamoxifen after 6 weeks of therapy was $107 \mathrm{ng} / \mathrm{ml}$, with a range from 24 to $317 \mathrm{ng} / \mathrm{ml}$ [5]. These data raise the question of whether one dose of tamoxifen 'fits' all patients. In addition, there is variability in tolerance of this drug, with differences in hot flashes, thromboembolic phenomena and endometrial cancers as examples. Compliance with tamoxifen

$\mathrm{Al}=$ aromatase inhibitor; $\mathrm{CYP}=$ cytochrome $\mathrm{P} 450 ; \mathrm{ER}=$ oestrogen receptor; GWAS = genome-wide association study; $4 \mathrm{HT}=4$-hydroxy-tamoxifen. 
has become increasingly recognized as an important issue, and a recent report [6] revealed that 49\% discontinued tamoxifen before the completion of 5 years. This poor compliance is of concern because nonadherent patients lose the therapeutic potential of this important drug.

For several decades, the tamoxifen metabolite $4 \mathrm{HT}$ has been considered to be the important metabolite from a therapeutic standpoint. Desta and coworkers [7] conducted a comprehensive examination of tamoxifen and found that the major primary metabolite of tamoxifen is $\mathrm{N}$-desmethyltamoxifen, in a reaction catalyzed by cytochrome $\mathrm{P} 450$ (CYP)3A4/5, whereas 4HT constitutes a minor metabolite, with this reaction catalyzed by several CYP enzymes, including CYP2D6. Importantly, $\mathrm{N}$-desmethyl-tamoxifen is converted to 4-hydroxy- $N$-desmethyl-tamoxifen (endoxifen) by CYP2D6. Endoxifen has been shown to have the same binding affinity for ER- $\alpha$ as $4 \mathrm{HT}$ [6] and to be equipotent to $4 \mathrm{HT}$ in terms of inhibiting oestrogen-stimulated growth in ERpositive breast cancer cell lines $[8,9]$. However, endoxifen is normally present in substantially higher concentrations, up to 10 times greater, than $4 \mathrm{HT}$ in women taking the standard dose of tamoxifen [10]. CYP2D6 is a highly polymorphic gene, with alleles with normal activity, decreased activity or no activity, and some cases of increased activity due to gene duplication [11]. Endoxifen levels were found to be low in those patients who had low activity CYP2D6 genotypes and/or were receiving CYP2D6 inhibitors [12,13].

Goetz and colleagues [14] were the first to identify an association between outcomes and CYP2D6 genotype in patients receiving tamoxifen monotherapy for 5 years. This retrospective study was performed in a well defined population of postmenopausal women with early-stage breast cancers whose tumours were known to be ER positive and who had been enrolled on a prospective clinical trial that had a median follow-up of 11.4 years [15]. Despite the relatively small sample size (223 patients) and the inclusion of only the *4 genotype, which underestimates the frequency of decreased activity, the women homozygous for the * 4 genotype $\left({ }^{*} 4 /{ }^{*} 4\right)$ had a worse relapse-free time and disease-free survival compared with those women without this variant allele or who carried only one (a heterozygous state [*4/wild type]). Although these differences were significant in univariate analyses, significance was lost in multivariate testing.

Goetz and colleagues [16] went on to collect information on these patients relating to the concurrent use of medications (selective serotonin reuptake inhibitors and the serotonin and norepinephrine reuptake inhibitors) that have been shown to inhibit CYP2D6 function [10,12,13]. When the genotype and presence or absence of the CYP2D6 inhibitor were utilized to determine a metabolizer phenotype, it was found in a multivariate analysis that patients with decreased metabolism had a significantly shorter time to recurrence and worse relapse-free survival. Since these initial reports, four additional studies have been reported that demonstrate an association between CYP2D6 status and outcomes in women receiving tamoxifen adjuvant therapy for early breast cancer. These include studies from Germany [17], Japan [18], the UK [19] and China [20].

Two groups had not identified CYP2D6 to have value in predicting outcomes in women treated with tamoxifen [21-23]. Despite the weight of evidence shifting in support of a positive value for CYP2D6 testing, the existence of conflicting data has led to the establishment of the International Tamoxifen Pharmacogenomics Consortium to collect and analyze the worldwide experience. The Consortium data center is PharmGKB (the Pharmacogenetics and Pharmacogenomics Knowledge Base) located at Stanford University in the USA [24]. This initiative is considered important in resolving the important question of whether simple genotyping for CYP2D6 can provide clinically useful information regarding the utilization of this commonly employed endocrine agent.

The fact that five studies have shown value for CYP2D6 is remarkable, given the complexity of tamoxifen's metabolism. This metabolic complexity plus the multiple phase II enzymes involved in glucuronidation and sulphate conjugation raises the distinct possibility that additional genotypes will be identified that could constitute a predictive panel that would be of value in clinical decision making.

\section{Aromatase inhibitors}

The third-generation Als anastrozole, exemestane and letrozole have found widespread use in breast cancer. An American Society of Clinical Oncology technology assessment panel on Als has concluded that optimal adjuvant therapy for postmenopausal women with receptor positive breast cancer includes an Al either as initial therapy or after treatment with tamoxifen [25].

Considering the Al anastrozole, Partridge and coworkers [26] examined adherence (defined as the proportion of days patients had medications available over an observation period) to this agent when given as adjuvant therapy for early breast cancer. Patients with fewer than $80 \%$ of days were considered nonadherent. This study of three health care plans involved more than 12,000 patients. The mean adherence ranged from $82 \%$ to $88 \%$ in year 1 and decreased to 625 to $79 \%$ in year 3. Thus, a substantial proportion of women were suboptimally adherent to anastrozole therapy.

The variability in clinical tolerance to Als raises the possibility that genetic variability in patients plays a role. Research into pharmacogenetic differences with the Als is at an earlier stage than with tamoxifen. However, Ma and colleagues [27] sequenced the aromatase gene in 60 patients from each of four ethnic groups (Caucasian-Americans, African-Americans, Han Chinese-Americans and Mexican-Americans) and identified 88 polymorphisms resulting in 44 haplotypes. 
Functional genomic studies were performed with four nonsynonymous coding single nucleotide polymorphisms that were identified and a significant correlation between level of activity and immunoreactive protein was found. Three of the four coding single nucleotide polymorphisms had levels of immunoreactive protein that was significantly lower than wildtype aromatase enzyme. It is possible that patients with decreased aromatase activity would have decreased potential to benefit from the use of an Al. The findings of substantial genetic variability in the aromatase gene within ethnic groups and substantial variation between the four ethnic groups provide a strong impetus to explore pharmacogenetics of Als.

The era of pharmacogenomics of Als has begun with the development of a study to perform a GWAS in women developing musculoskeletal events in a large clinical trial evaluating Als. This study is a part of a Global Alliance for Pharmacogenomics between the US National Institutes of Health Pharmacogenetics Research Network and the RIKEN Center for Genomic Medicine in Japan [28], and involves the Mayo Pharmacogenetics Research Network, the National Cancer Institute of Canada Clinical Trials Group and RIKEN. Whereas the initial studies will involve an evaluation of adverse events, future studies are envisioned that will examine breast cancer events.

\section{Conclusion}

The field of pharmacogenetics is at an early stage in the endocrine therapy of breast cancer. The information that has emerged with CYP2D6 appears to offer the potential to fulfill the clinical goal of better selecting patients for whom tamoxifen should be employed, but further validation is needed before widespread acceptance. Pharmacogenetics/ genomics are at an earlier stage with the Als. The era of pharmacogenomics has been entered with the availability of GWASs. It is anticipated that results will become available for both tamoxifen and the Als over the next several years. Compliance with a drug is obviously multifactorial and includes adverse events as only one factor. However, compliance is a crucial consideration, because noncompliance with both tamoxifen and Als carries with it the loss of potential for benefit from therapy. In endocrine therapy of breast cancer, pharmacogenetics/pharmacogenomics offer the potential of identifying the right drug at the right dose for the right patient.

\section{Competing interests}

The author declares that they have no competing interests.

\section{Acknowledgement}

This article has been published as part of Breast Cancer Research Volume 10 Supplement 4, 2008: Controversies in Breast Cancer 2008. The full contents of the supplement are available online at http://breast-cancer-research.com/supplements/10/S4

\section{References}

1. Ingle JN, Suman VJ: Aromatase inhibitors for therapy of advanced breast cancer. J Steroid Biochem Mol Biol 2005, 95:113-119.
2. Ingle JN: Adjuvant endocrine therapy for postmenopausal women with early breast cancer. Clin Cancer Res 2006, 12 (suppl S):1031S-1036S.

3. Ingle JN: Endocrine therapy trials of aromatase inhibitors for breast cancer in the adjuvant and prevention settings. Clin Cancer Res 2005, 11(suppl S):900S-905S.

4. Ingle JN: Pharmacogenomics of tamoxifen and aromatase inhibitors. Cancer 2008, 112(suppl):695-699.

5. Ingle JN, Suman VJ, Johnson PA, Krook JE, Mailliard JA, Wheeler $\mathrm{RH}$, Loprinzi CL, Perez EA, Jordan VC, Dowsett M: Evaluation of tamoxifen plus letrozole with assessment of pharmacokinetic interaction in postmenopausal women with metastatic breast cancer. Clin Cancer Res 1999, 5:1642-1649.

6. Owusu C, Buist DS, Field TS, Lash TL, Thwin SS, Geiger AM, Quinn VP, Frost F, Prout M, Yood MU, Wei F, Silliman RA: Predictions of tamoxifen discontinuation among older women with estrogen receptor-positive breast cancer. J Clin Oncol 2008, 26:549-555.

7. Desta Z, Ward BA, Soukhova NV, Flockhart DA: Comprehensive evaluation of tamoxifen sequential biotransformation by the human cytochrome P450 system in vitro: prominent roles for CYP3A and CYP2D6. J Pharmacol Exp Ther 2004, 310:10621075.

8. Johnson MD, Zuo H, Lee KH, Trebley JP, Rae JM, Weatherman RV, Desta Z, Flockhart DA, Skaar TC: Pharmacologic characterization of 4-hydroxy- $\mathrm{N}$-desmethyl tamoxifen, a novel active metabolite of tamoxifen. Breast Cancer Res Treat 2004, 85: 151-159.

9. Lim YC, Desta Z, Flockhart DA, Skaar TC: Endoxifen (4hydroxy-N-desmethyl-tamoxifen) has anti-estrogenic effects in breast cancer cells with potency similar to 4-hydroxytamoxifen. Cancer Chemother Pharmacol 2005, 55:471-478.

10. Stearns V, Johnson MD, Rae JM, Morocho A, Novielli A, Bhargava P, Hayes DF, Desta Z, Flockhart DA: Active tamoxifen metabolite plasma concentrations after coadministration of tamoxifen and the selective serotonin reuptake inhibitor paroxetine. J Natl Cancer Inst. 2003, 95:1758-1764.

11. Ingelman-Sundberg M: Genetic polymorphisms of cytochrome P450 2D6 (CYP2D6): clinical consequences, evolutionary aspects and functional diversity. Pharmacogenomics J 2005, 5: 6-13.

12. Jin $Y$, Desta $Z$, Stearns $V$, Ward $B$, Ho H, Lee $K H$, Skaar $T$, Storniolo AM, Li L, Araba A, Blanchard R, Nguyen A, Ullmer L, Hayden J, Lemler S, Weinshilboum RM, Rae JM, Hayes DF, Flockhart DA: CYP2D6 genotype, antidepressant use, and tamoxifen metabolism during adjuvant breast cancer treatment. $J$ Natl Cancer Inst 2005, 97:30-39.

13. Borges S, Desta Z, Li L, Skaar TC, Ward BA, Nguyen A, Jin Y, Storniolo AM, Nikoloff DM, Wu L, Hillman G, Hayes DF, Stearns V, Flockhart DA: Quantitative effect of CYP2D6 genotype and inhibitors on tamoxifen metabolism: implication for optimization of breast cancer treatment. Clin Pharmacol Ther 2006, 80: 61-74.

14. Goetz MP, Rae JM, Suman VJ, Safgren SL, Ames MM, Visscher DW, Reynolds C, Couch FJ, Lingle WL, Flockhart DA, Desta Z, Perez EA, Ingle JN: Pharmacogenetics of tamoxifen biotransformation is associated with clinical outcomes of efficacy and hot flashes. J Clin Onco/ 2005, 23:9312-9318.

15. Ingle JN, Suman VJ, Mailliard JA, Kugler JW, Krook JE, Michalak JC, Pisansky TM, Wold LE, Donohue JH, Goetz MP, Perez EA: Randomized trial of tamoxifen alone or combined with fluoxymesterone as adjuvant therapy in postmenopausal women with resected estrogen receptor positive breast cancer. North Central Cancer Treatment Group Trial 89-30-52. Breast Cancer Res Treat 2006, 98:217-222.

16. Goetz MP, Knox SK, Suman VJ, Rae JM, Safgren SL, Ames MM, Visscher DW, Reynolds C, Couch FJ, Lingle WL, Weinshilboum RM, Fritcher EG, Nibbe AM, Desta Z, Nguyen A, Flockhart DA, Perez EA, Ingle JN: The impact of cytochrome P450 2D6 metabolism in women receiving adjuvant tamoxifen. Breast Cancer Res Treat 2007, 101:113-121.

17. Schroth W, Antoniadou L, Fritz P, Schwab M, Muerdter T, Zanger UM, Simon W, Eichelbaum M, Brauch H: Breast cancer treatment outcome with adjuvant tamoxifen relative to patient CYP2D6 and CYP2C19 genotypes. J Clin Oncol 2007, 25:5187-5193.

18. Kiyotani K, Mushiroda T, Sasa M, Bando Y, Sumitomo I, Hosono N, Kubo M, Nakamura Y, Zembutsu H: Impact of CYP2D6*10 on 
recurrence-free survival in breast cancer patients receiving adjuvant tamoxifen therapy. Cancer Sci 2008, 99:995-999.

19. Newman WG, Hadfield KD, Latif A, Roberts SA, Shenton A McHague C, Lalloo F, Howell S, Evans DG: Impaired tamoxifen metabolism reduces survival in familial breast cancer patients. Clin Cancer Res 2008, 14:5913-5918.

20. Xu Y, Sun Y, Yao L, Shi L, Wu Y, Ouyang T, Li J, Wang T, Fan Z, Fan T, Lin B, He L, Li P, Xie Y: Association between CYP2D6*10 genotypes and survival of breast cancer patients receiving tamoxifen treatment. Ann Oncol 2008, 19:1423-1429.

21. Wegman $P$, Vainikka L, Stål O, Nordenskjöld B, Skoog L, Rutqvist LE, Wingren S: Genotype of metabolic enzymes and the benefit of tamoxifen in postmenopausal breast cancer patients. Breast Cancer Res 2005, 7:R284-R290.

22. Nowell SA, Ahn J, Rae JM, Scheys JO, Trovato A, Sweeney C, MacLeod SL, Kadlubar FF, Ambrosone CB: Association of genetic variation in tamoxifen-metabolizing enzymes with overall survival and recurrent of disease in breast cancer patients. Breast Cancer Res Treat 2005, 91:249-258.

23. Wegman $P$, Elingarami $S$, Carstensen J, Stål O, Nordenskjöld B, Wingren S: Genetic variants of CYP3A5, CYP2D6, SULT1A1, UGT2B15 and tamoxifen response in postmenopausal patients with breast cancer. Breast Cancer Res 2007 9:R7.

24. PharmGKB: the Pharmacogenetics and Pharmacogenomics Knowledge Base [http://www.pharmgkb.org]

25. Winer EP, Hudis C, Burstein HJ, Wolff AC, Pritchard KI, Ingle JN, Chlebowski RT, Gelber R, Edge SB, Gralow J, Cobleigh MA, Mamounas EP, Goldstein LJ, Whelan TJ, Powles TJ, Bryant J, Perkins C, Perotti J, Braun S, Langer AS, Browman GP, Somerfield MR: American Society of Clinical Oncology technology assessment of the use of aromatase inhibitors as adjuvant therapy for postmenopausal women with hormone receptorpositive breast cancer: status report 2004. J Clin Oncol 2005, 23:619-629.

26. Partridge $\mathrm{AH}$, LaFountain A, Mayer E, Taylor BS, Winer E, AsnisAlibozek A: Adherence to initial adjuvant anastrozole therapy among women with early-stage breast cancer. J Clin Oncol 2008, 26:556-562.

27. Ma CX, Adjei AA, Salavaggione OE, Coronel J, Pelleymounter L, Wang L, Eckloff BW, Schaid D, Wieben ED, Adjei AA, Weinshilboum RM: Human aromatase: gene resequencing and functional genomics. Cancer Res 2005, 65:11071-11082.

28. Global Alliance for Pharmacogenomics [http://www.nigms.nih. gov/Initiatives/PGRN/GAP/] 